\title{
Reduction in the in vitro sensitivity oF Drechslera tritici-repentis, isolated from wheat, to strobilurin and triazole fungicides
}

\author{
Rosane Baldiga Tonin ${ }^{1}$; Erlei Melo Reis ${ }^{1,2}$; Aveline Avozani ${ }^{1}$
}

\begin{abstract}
${ }^{1}$ Laboratório de Fitopatologia - Micologia, Faculdade de Agronomia e Medicina Veterinária, Universidade de Passo Fundo - UPF, 99001-970, Passo Fundo, RS, Brasil. ${ }^{2}$ Bolsista do CNPq.

Autor para correspondência: Erlei Melo Reis (erleireis@upf.br)

Data de chegada: 22/02/2016. Aceito para publicação em: 13/05/2016.
\end{abstract}

$10.1590 / 0100-5405 / 2160$

\section{ABSTRACT}

Tonin, R. B; Reis, E. M.; Avozani, A. Reduction in the in vitro sensitivity of Drechslera tritici-repentis, isolated from wheat, to strobilurin and triazole fungicides. Summa Phytopathologica, v.43, n.1, p.20-25, 2017.

Reports of failure in the chemical control of wheat yellow leaf spot led to determination of the sensitivity of Drechslera tritici-repentis (Dtr) to the fungicides quinone outside inhibitors (QoIs) and demethylation inhibitors (DMIs). The $\mathrm{IC}_{50}$ was obtained for strobilurins (azoxystrobin, kresoxim-methyl, picoxystrobin and pyraclostrobin) and for triazoles (cyproconazole, epoxiconazole, propiconazole, prothioconazole and tebuconazole), using five Dtr isolates. Seven concentrations of the fungicides were tested in the bioassay: $0.00 ; 0.01 ; 0.10 ; 1.00 ; 10: 00$ and 20.00 and $40.00 \mathrm{mg} / \mathrm{L}$ active ingredient (a.i.). Assays consisted of completely randomized design and four replicates. Each experiment was performed twice, using the average of the two tests for statistical analysis. The percentage inhibition data for conidial germination
(QoIs) and for mycelial growth (DMIs) were subjected to logarithmic regression analysis, calculating the $50 \%$ inhibitory concentration $\left(\mathrm{IC}_{50}\right)$ based on the generated equation. There was a reduction in the sensitivity of $D t r$ isolates to strobilurins. $\mathrm{IC}_{50}$ values ranged from 0.58 to $>40.00$ $\mathrm{mg} / \mathrm{L}$. The lowest sensitivity of isolates was detected for azoxystrobin, kresoxim-methyl, picoxystrobin and trifloxystrobin. Pyraclostrobin was most efficient, showing $\mathrm{IC}_{50}$ between 0.58 and $1.03 \mathrm{mg} / \mathrm{L}$. The $\mathrm{IC}_{50}$ ranged from 0.35 to $1.37 \mathrm{mg} / \mathrm{L}$ for epoxiconazole, from 0.49 to 1.28 $\mathrm{mg} / \mathrm{L}$ for propiconazole and from 1.41 to $2.34 \mathrm{mg} / \mathrm{L}$ for tebuconazole. Prothioconazole was most potent, showing $\mathrm{IC}_{50}$ between 0.09 and 0.21 $\mathrm{mg} / \mathrm{L}$. The hypothesis that the control failure can be attributed to the reduced Dtr sensitivity to the fungicides QoIs and DMIs was confirmed.

Keywords: $\mathrm{IC}_{50}$, fungitoxicity, QoIs, yellow spot, Pyrenophora tritici-repentis, Triticum aestivum.

\section{RESUMO}

Tonin, R. B; Reis, E. M.; Avozani, A. Redução da sensibilidade in vitro de Drechslera tritici-repentis, isolados do trigo, a fungicidas estrobilurinas e triazóis, in vitro. Summa Phytopathologica, v.43, n.1, p.20-25, 2017.

Devido a relatos da ocorrência de falha de controle químico da manchaamarela da folha do trigo, determinou-se a sensibilidade de Drechslera tritici-repentis (Dtr) aos fungicidas inibidores da quinona externa (IQe) e aos inibidores da desmetilação (IDMs). ACI $_{50}$ foi determinada para as estrobilurinas (azoxistrobina, cresoxim-metílico, picoxistrobina e piraclostrobina), para os triazóis (ciproconazol, epoxiconazol, propiconazol, protioconazol e tebuconazol) e usando cinco isolados de Dtr de trigo. Sete concentrações dos fungicidas foram testadas no bioensaio: 0,$00 ; 0,01 ; 0,10 ; 1,00 ; 10,00$; 20,00 e $40,00 \mathrm{mg} / \mathrm{L}$ de ingrediente ativo (i.a.). Os ensaios constituiuramse de delineamento inteiramente casualizados, com quatro repetições. Cada experimento foi realizado duas vezes utilizando-se para a análise estatística as médias dos dois testes. Os dados da porcentagem da inibição da germinação de conídios (IQes) e do crescimentoe do micélio (IDMs) foram submetidos à análise de regressão logarítmica, calculando-se a concentração inibitória de $50 \%\left(\mathrm{CI}_{50}\right)$ através da equação gerada. Foi verificada redução da sensibilidade de isolados de Dtr para as estrobilurinas. Valores da $\mathrm{CI}_{50}$ situaram-se entre $0,58 \mathrm{a}>40,00 \mathrm{mg} / \mathrm{L}$. A menor sensibilidade dos isolados, foi detectada para azoxistrobina, cresoxim-metílico, picoxistrobina e trifloxistrobina. A piraclostrobina mostrou-se o mais eficiente, com $\mathrm{CI}_{50}$ entre 0,58 a $1,03 \mathrm{mg} / \mathrm{L}$. A CI $_{50}$ para o epoxiconazol situou-se entre 0,35 a $1,37 \mathrm{mg} / \mathrm{L}$, para propiconazol de 0,49 a $1,28 \mathrm{mg} / \mathrm{L}$ e de 1,41 a $2,34 \mathrm{mg} / \mathrm{L}$ para tebuconazol. O protioconazol foi o mais potente, com $\mathrm{CI}_{50}$ entre 0,09 a $0,21 \mathrm{mg} / \mathrm{L}$. Confirmou-se a hipótese de que a falha de controle pode ser atribuída a redução da sensibilidade de $D t r$ aos fungicidas IQes e IDMs.

Palavras-chave: $\mathrm{CI}_{50}$ fungitoxicidade, IQes, mancha-amarela, Pyrenophora tritici-repentis, Triticum aestivum

The fungus Pyrenophora tritici-repentis (Died.) Drechs. (anamorph Drechslera ritici-repentis (Died.) Shoem. is the causal agent of yellow leaf spot (YLS) of wheat $(12,15,16)$. This disease has been a threat to wheat production in many countries $(12,14,15,16)$. Damage caused to wheat by YLS can be calculated based on the normalized function $\mathrm{Y}=1,000-5.7 \mathrm{I}(\mathrm{Y}=$ yield $\mathrm{kg} / \mathrm{ha}$ and $\mathrm{I}=$ leaf incidence $)(16)$.

In Southern Brazil, YLS has been predominant among wheat diseases in recent seasons (27). It is related to no-tillage and wheat monoculture since this pathogen is a necrotrophic fungus that survives in crop debris in its teleomorph state and in other hosts such as rye (Secale cereale L.) and triticale (Triticum secalotricum Meister) (14).

Integrated management of YLS is achieved by the use of tolerant cultivars, healthy seeds, seed lots treated with efficient fungicide, crop rotation and fungicide application on the foliage (16). Genetic resistance is a very important control measure; however, in Brazil, a resistant cultivar to control YLS of wheat is not available (23).

Two fungicide groups have been used to control wheat diseases, triazoles and strobilurins. Among triazoles or demethylation inhibitors 
(DMI), cyproconazole, epoxiconazole and tebuconazole have been intensively employed by farmers to control the pathogen; their use alone or in mixture with quinone outside inhibitors (QoI) or strobilurins is recommended $(3,7,9)$. The fungicide propiconazole was first used in the 1986 growing season (18), tebuconazole in the $1991(19,20)$, cyproconazole in the 1993 (21), and epoxiconazole in the 2000 growing season (22). After fifteen years of triazole use, the first complaint of failure to control leaf rust caused by Puccinia triticina Eriks. was reported (2).

Fungicide application is one of the main methods to control plant diseases; however, repeated use in different growing seasons can promote the selection of resistant strains of pathogenic fungi (11). Currently, sensitivity reduction has been one of the most important problems faced by the chemical control of plant diseases $(4,6,11,25)$.

The sensitivity of a fungus to a certain fungicide or the chemical fungitoxicity is measured by adopting parameters such as $\mathrm{ED}_{50}$ (effective dose to promote a desired effect in $50 \%$ of the microorganisms subjected to the test), $\mathrm{LD}_{50}$ (lethal dose), $\mathrm{LC}_{50}$ (lethal concentration), $\mathrm{EC}_{50}$ (effective concentration) $\mathrm{MIC}$ (minimum inhibitory concentration), $\mathrm{GI}_{50}$ (growth inhibition) and $\mathrm{IC}_{50}$ (inhibitory concentration to inhibit by $50 \%$ the mycelial growth and/or spore germination) $(11,25)$.

There are few studies monitoring the sensitivity of Drechslera ritici-repentis (Dtr) to fungicides recommended by the Brazilian wheat research to pathogen control. Fungicides have been intensively employed by farmers, and their mixtures DMI + QoI are recommended for pathogen control (23).

The shift in sensitivity of a pathogen to a specific fungicide can compromise the efficacy of chemical control of diseases such as leaf rust (2) and powdery mildews (17). Thus, monitoring the sensitivity of a pathogen population to fungicides is important to maintain the control efficiency.

A large number of farm advisers and growers have complained about failure in the chemical control of YLS in the last growing seasons after continuous use of fungicides for almost 20 years. The first step towards a scientific explanation for control failure is to measure the sensitivity of the fungus to the commonly used fungicide.

We hypothesized that YLS control failure could be due to the shift in the pathogen sensitivity to fungicides used in the wheat field for a long time.

The aim of this study was to determine the sensitivity of $D t r$ isolates from wheat to QoI and DMI fungicides considering spore germination and mycelial growth.

\section{MATERIAL AND METHODS}

Isolates of Drechslera tritici-repentis. The isolates were obtained from wheat leaves showing symptoms of the disease, collected from fields in the states of Paraná and Rio Grande do Sul (Table 1).

Table 1. Origin and identification of Drechslera tritici-repentis isolates

\begin{tabular}{cccc}
\hline Isolate & Wheat cultivar & County/State & Identification \\
\hline 01 & Quartzo & Ventania - PR & $01 / \mathrm{QTZ}$ \\
02 & Onix & Santo Augusto - RS & $02 / \mathrm{ONX}$ \\
03 & Horizonte & Júlio de Castilhos - RS & $03 / \mathrm{HZT}$ \\
04 & Guamirim & Coxilha - RS & $04 / \mathrm{GUA}$ \\
05 & CD 104 & Pitangueiras $-\mathrm{PR}$ & $05 / \mathrm{CD}$ \\
\hline
\end{tabular}

Test with strobilurins - Spore germination. To evaluate the sensitivity of Dtr spore germination to fungicides, a bioassay was performed by incorporating the fungicides in water agar medium, similarly to the method described by Russell (2004).

Fungicides. The following QoI fungicides were used in the test: azoxystrobin (Priori 250 SC), kresoxim-methyl (Stroby 500 SC), picoxystrobin (Oranis $250 \mathrm{SC}$ ), pyraclostrobin (Comet $250 \mathrm{EC}$ ) and trifloxystrobin (Twist $125 \mathrm{CE}$ ). These fungicides are recommended to be used in mixture (QoIs + DMIs) for the control of YLS in wheat, except picoxystrobin (Reunião, 2011).

Fungicides were initially diluted in sterile distilled water (SDW) to obtain the desired concentrations. Six active ingredient concentrations were used in the bioassay: $0.00,0.01,0.10,1.00,10.00,20.00$ and 40.00 $\mathrm{mg} / \mathrm{L}$. The $0.00 \mathrm{mg} / \mathrm{L}$ concentration, or no fungicide, represented the control of each experiment.

Spore suspensions of each Dtr isolate were prepared by using colonies with abundant sporulation of the pathogen after seven days of growth in V8 agar medium. Spores were removed by scraping the colony with a camel's hair brush number 20 , containing approximately $10 \mathrm{ml}$ of sterile distilled water. A $350-\mu \mathrm{L}$ aliquot of the spore suspension of each isolate was poured onto each Petri dish containing the medium supplemented with the fungicide concentrations. Petri dishes were kept in a BOD incubator (Biological Oxygen Demand) (Marconi, Piracicaba, SP) at $22 \pm 1{ }^{\circ} \mathrm{C}$, under continuous light provided by three fluorescent lamps OSRAM Universal, $40 \mathrm{~W}$, at $15 \mathrm{~cm}$ above the plates for eight hours.

Spore germination assessment. After eight-hour exposure, germination was stopped by adding drops of acetone (100\%) plus a cotton blue dye in each Petri dish. Germination assessment was performed by scanning at random 100 conidia per plate under an optical microscope, $400 \mathrm{X}$ magnification, per replicate. Conidia showing a germ tube length equal to or greater than the smallest spore diameter were considered germinated (28).

Test with DMI fungicides - Mycelial inhibition. The DMI fungicides cyproconazole (Alto 100, $100 \mathrm{SL}$ ), epoxiconazole (Opus 125 SC), propiconazole (Tilt 250 EC), prothioconazole (Proline 250 EC) and tebuconazole (Folicur $200 \mathrm{EC}$ ) were used in the test. These fungicides are recommended to be used in mixture with QoIs to control YLS in wheat crop (20). Prothioconazole, a novel fungicide, was employed to compare its performance with that of the traditionally used fungicides.

The concentrations of each assessed fungicide were: $0.00 ; 0.01$; $0.10 ; 1.00 ; 10.00 ; 20.00$ and $40.00 \mathrm{mg} / \mathrm{L}$ a.i. For dilution, fungicide aliquots were transferred with a micropipette to a flask containing sterile distilled water (SDW), resulting in a final volume of $100 \mathrm{ml}$ (base 1 suspension). One $\mathrm{mL}$ from this first suspension was transferred to 99.0 $\mathrm{mL}$ SDW in a volumetric flask, constituting the second dilution solution (base 2 suspension). Required volumes of the base 2 suspension were added to wheat leaf extract agar medium (WLEA) (3 $\mathrm{g}$ wheat leaf, 20 $\mathrm{g}$ dehydrated PDA, $8 \mathrm{~g}$ agar, $1.0 \mathrm{~L}$ distilled water) to obtain the desired concentrations. Flasks were carefully shaken and the supplemented medium was poured onto sterilized Petri dishes (90 diameter x $15 \mathrm{~mm}$ height) in a laminar flow hood.

Discs of $5 \mathrm{~mm}$ diameter containing fungal mycelium, taken from the edge of the seven-day-old colonies, were transferred to Petri dishes containing WLEA supplemented with the fungicide concentrations. Plates were incubated in a growth chamber at $25 \pm 2{ }^{\circ} \mathrm{C}, 12 \mathrm{~h}$ photoperiod; light was provided by three fluorescent lamps, $40 \mathrm{~W}$, at $50 \mathrm{~cm}$ above the plates, which were randomly distributed on shelves.

Mycelial growth assessment. Mycelial inhibition was obtained by measuring with a digital caliper (Mitutoyo) the radial growth of 
colonies in two perpendicular diameters when the fungal growth in the control treatment reached the plate edge.

Experimental design. A complete randomized factorial design ( 5 fungicides $\mathrm{x} 5$ isolates) was adopted with four replicates, and each experimental unit was represented by a Petri dish. Experiments were repeated twice and means were used in statistical analysis. Mycelial growth data, as centimeters, were converted into percent inhibition.

Data analysis. Data were subjected to logarithmic regression analysis and the concentration that inhibits $50 \%$ spore germination or mycelium growth $\left(\mathrm{IC}_{50}\right)$ was calculated, using the statistical program Costat.

Classification of isolates' sensitivity. Isolates were classified according to Edgington et al. (8) adapted to the following criteria: insensitive, $\mathrm{IC}_{50}>40 \mathrm{mg} / \mathrm{L}$; low sensitivity, $\mathrm{IC}_{50}$ between 10 and $40 \mathrm{mg} / \mathrm{L}$; moderately sensitive, $\mathrm{IC}_{50}$ between 1 and $10 \mathrm{mg} / \mathrm{L}$; highly sensitive, $\mathrm{IC}_{50}<1 \mathrm{mg} / \mathrm{L}$. The $\mathrm{IC}_{50}$ is defined as the concentration of active ingredient that inhibits by $50 \%$ spore germination or mycelial growth.

Sensitivity reduction factor. To detect the magnitude of the fungus shift in sensitivity to fungicides, the sensitivity reduction factor (SRF) was calculated by dividing the $\mathrm{IC}_{50}$ of the suspected isolate by the $\mathrm{IC}_{50}$ of the most sensitive isolate. When the SRF value was equal to 1 , there was no shift in sensitivity, and when the SRF value was $>1$, there was sensitivity reduction

\section{RESULTS}

Drechslera tritici-repentis sensitivity to strobilurins. The $\mathrm{IC}_{50}$ values for $01 / \mathrm{QTZ}$ isolate ranged from 0.75 to $>40 \mathrm{mg} / \mathrm{L}$. Based on the average of the two experiments, this isolate was considered sensitive to pyraclostrobin $(0.75 \mathrm{mg} / \mathrm{L})$, showing $\mathrm{IC}_{50}$ lower than $1.0 \mathrm{mg} / \mathrm{L}$, and was insensitive to azoxystrobin, kresoxim-methyl, trifloxystrobin and picoxystrobin, showing $\mathrm{IC}_{50}>40 \mathrm{mg} / \mathrm{L}$ (Table 2).

$02 / \mathrm{ONX}$ isolate was considered insensitive, showing values greater than $1 \mathrm{mg} / \mathrm{L}$ for azoxystrobin, kresoxim-methyl, trifloxystrobin and picoxystrobin $(>40 \mathrm{mg} / \mathrm{L})$. Values lower than $1.0 \mathrm{mg} / \mathrm{L}$ were found for pyraclostrobin $(0.85 \mathrm{mg} / \mathrm{L})$. This isolate was classified as sensitive to this active ingredient (Table 2).

03/HTZ is olate was considered sensitive to pyraclostrobin and insensitive to the other fungicides (Table 2).

$04 / \mathrm{GUA}$ isolate was highly sensitive to pyraclostrobin $(0.58 \mathrm{mg} / \mathrm{L})$. Values greater than $1.0 \mathrm{mg} / \mathrm{L}$ were found for azoxystrobin, kresoximmethyl, trifloxystrobin and picoxys trobin $(>40 \mathrm{mg} / \mathrm{L})$. Thus, this isolate was considered insensitive to these active ingredients (Table 2).
The $\mathrm{IC}_{50}$ for $05 / \mathrm{CD}$ isolate ranged from 1.03 to $>40 \mathrm{mg} / \mathrm{L}$. This isolate was classified as insen sitive to azoxystrobin $(>40$ $\mathrm{mg} / \mathrm{L})$, kresoxim-methyl (> $40 \mathrm{mg} / \mathrm{L})$, picoxystrobin ( $>40 \mathrm{mg} / \mathrm{L})$, pyraclostrobin $(1.03 \mathrm{mg} / \mathrm{L})$ and trifloxystrobin $(>40 \mathrm{mg} / \mathrm{L})$, which means that these active ingredients were nontoxic to this isolate, demonstrating a sensitivity reduction to these fungicides (Table 2).

Interaction between isolates and fungicides was significant $(p$ $<0.05$ ) (Table 4). On average, pyraclostrobin showed the lowest $\mathrm{IC}_{50}$ for the five isolates, ranging from 0.58 to $1.03 \mathrm{mg} / \mathrm{L}$. On the other hand, the $\mathrm{IC}_{50}$ for azoxystrobin, kresoxim-methyl, trifloxystrobin and pycoxistrobin was higher than $40 \mathrm{mg} / \mathrm{L}$ (Table 2).

The lowest $\mathrm{IC}_{50}$ was determined for $04 / \mathrm{GUA}$ isolate when tested with pyraclostrobin, the most fungitoxic fungicide, showing $\mathrm{IC}_{50}$ of $0.58 \mathrm{mg} / \mathrm{L}$ (Table 2).

None of the active ingredients, azoxystrobin, kresoxim-methyl, picoxystrobin and trifloxystrobin, inhibited $100 \%$ spore germination using the six tested concentrations. Moreover, the fungicide pyraclostrobin showed crescent inhibition as the active ingredient concentration increased.

Drechsler a tritici-repentis sensitivity to DMIs. Regarding the effects of cyproconazole, epoxiconazole, propiconazole, prothioc onazole and tebuconazole, none of them inhibited $100 \%$ fungal mycelial growth at the concentrations of $0.01,0.1$ and $1.0 \mathrm{mg} / \mathrm{L}$ (Table 3).

The sensitivity of fungal isolates was classified based on the standard criterion of Edgington et al. (8). After analyzing our data, a modified classification was proposed: $\mathrm{IC}_{50}>40 \mathrm{mg} / \mathrm{L}$, insensitive; $\mathrm{IC}_{50}$ between 10 and $40 \mathrm{mg} / \mathrm{L}$, low sensitivity; $\mathrm{IC}_{50}$ between 1 and $10 \mathrm{mg} / \mathrm{L}$, moderately sensitive, and $\mathrm{IC}_{50}<1 \mathrm{mg} / \mathrm{L}$, highly sensitive isolate (Table 3).

$01 /$ QTZ is olate was considered sensitive according to our classification, showing $\mathrm{IC}_{50}$ values lower than $1.0 \mathrm{mg} / \mathrm{L}$ for prothioconazole and propiconazole. $\mathrm{IC}_{50}$ ranged from $0.86 \mathrm{mg} / \mathrm{L}$ for propiconazole and $0.18 \mathrm{mg} / \mathrm{L}$ for prothioconazole. The strain was considered moderately sensitive to the fungicides epoxiconazole, $\mathrm{IC}_{50}$ value of $1.37 \mathrm{mg} / \mathrm{L}$, and tebuconazole, $\mathrm{IC}_{50}$ value of $1.84 \mathrm{mg} / \mathrm{L}$. In addition, the strain was considered insensitive to the active ingredient cyproconazole, showing $\mathrm{IC}_{50}$ value $>40 \mathrm{mg} / \mathrm{L}$ (Table 3 ).

$02 / \mathrm{ONX}$ isolate was highly sensitive to epoxiconazole and prothioc onazole. Its $\mathrm{IC}_{50}$ values ranged from $0.35 \mathrm{mg} / \mathrm{L}$ for epoxiconazole and $0.16 \mathrm{mg} / \mathrm{L}$ for prothioconazole. Values greater than $1.0 \mathrm{mg} / \mathrm{L}$ were observed for propiconazole, between $1.28 \mathrm{mg} / \mathrm{L}$ and $2.34 \mathrm{mg}$, and for tebuconazole; the isolate was considered moderately sensitive to these active ingredients and classified to have low sensitivity to cyproconazole ( $\mathrm{IC}_{50}$ of $28.11 \mathrm{mg} / \mathrm{L}$ ) (Table 3 ).

Table 2. Concentrations (mg/L) of QoI fungicides to inhibit 50\% spore germination $\left(\mathrm{IC}_{50}\right)$ of Drechslera tritici-repentis isolates

\begin{tabular}{|c|c|c|c|c|c|c|}
\hline \multirow[t]{2}{*}{ Fungicide } & \multicolumn{5}{|c|}{ Isolates $\left(\mathrm{CI}_{50} \mathrm{mg} / \mathrm{L}\right)$} & \multirow{2}{*}{ Mean } \\
\hline & 01/QTZ & $02 /$ ONX & 03/HZT & 04/GUA & $05 / \mathrm{CD}$ & \\
\hline Azoxystrobin & $\mathrm{A}>40 \mathrm{a}$ & $\mathrm{A}>40 \mathrm{a}$ & $\mathrm{A}>40 \mathrm{a}$ & $\mathrm{A}>40 \mathrm{a}$ & $\mathrm{A}>40 \mathrm{a}$ & $>40 \mathrm{a}$ \\
\hline Picoxystrobin & $\mathrm{A}>40 \mathrm{a}$ & $\mathrm{A}>40 \mathrm{a}$ & $\mathrm{A}>40 \mathrm{a}$ & $\mathrm{A}>40 \mathrm{a}$ & $\mathrm{A}>40 \mathrm{a}$ & $>40 \mathrm{a}$ \\
\hline Pyraclostrobin & D $0.75 b$ & B $0.85 \mathrm{~b}$ & $\mathrm{C} 0.78 \mathrm{~b}$ & E $0.58 \mathrm{~b}$ & A $1.03 \mathrm{~b}$ & $0.80 \mathrm{~b}$ \\
\hline CV (\%) & 0.02 & & & & & \\
\hline
\end{tabular}

Means followed by the same letter do not differ according to Tukey's test at $5 \%$. Lowercase letters compare means in the column and capital letters, in the lines. Means of two experiments, 
Table 3. Concentrations $(\mathrm{mg} / \mathrm{L})$ of DMI fungicides to inhibit 50\% mycelial growth $\left(\mathrm{IC}_{50}\right)$ of Drechslera tritici-repentis isolates

\begin{tabular}{|c|c|c|c|c|c|c|}
\hline \multirow{2}{*}{ Fungicide } & \multicolumn{5}{|c|}{ Isolates } & \multirow{2}{*}{ Mean } \\
\hline & 01/QTZ & $02 / \mathrm{ONX}$ & 03/HZT & 04/GUA & $05 / C D$ & \\
\hline Cyproconazole & $\mathrm{A}>40.0 \mathrm{a}$ & C $28.11 \mathrm{a}$ & $\mathrm{A}>40.0 \mathrm{a}$ & $\mathrm{A}>40.0 \mathrm{a}$ & B $34.08 \mathrm{a}$ & $>36.44 \mathrm{a}$ \\
\hline Propiconazole & $\mathrm{AB} 0.86 \mathrm{c}$ & A $1.28 \mathrm{c}$ & B $0.49 \mathrm{~cd}$ & B $0.50 \mathrm{c}$ & A $1.17 \mathrm{c}$ & $0.86 \mathrm{c}$ \\
\hline Prothioconazole & A $0.18 \mathrm{~d}$ & A $0.16 \mathrm{~d}$ & A $0.21 \mathrm{~d}$ & A 0.09 c & A $0.17 \mathrm{~d}$ & $0.16 \mathrm{~d}$ \\
\hline CV (\%) & 2.77 & & & & & \\
\hline
\end{tabular}

Means followed by same letter do not differ according to Tukey's test at 5\%. Capital letters compare means in the column and lowercase letters, in the line. Mean of two experiments.

03/HTZ isolate was classified as insensitive to cyproconazole, showing $\mathrm{IC}_{50}$ value $>40 \mathrm{mg} / \mathrm{L}$, the lowest sensitivity to this fungicide. Similar results were found for the other strains. $\mathrm{IC}_{50}$ values ranged from $0.49 \mathrm{mg} / \mathrm{L}$ for propiconazole to $0.21 \mathrm{mg} / \mathrm{L}$ for prothioconazole. This strain was considered moderately sensitive to the fungicides epoxiconazole $\left(\mathrm{IC}_{50}=1.11 \mathrm{mg} / \mathrm{L}\right)$ and tebuconazole $\left(\mathrm{IC}_{50}=1.82 \mathrm{mg} / \mathrm{L}\right)$ (Table 3).

04/GUA isolate had $\mathrm{IC}_{50}<1 \mathrm{mg} / \mathrm{L}$ for $0.63 \mathrm{mg} / \mathrm{L}$ epoxiconazole, $0.50 \mathrm{mg} / \mathrm{L}$ propiconazole and $0.09 \mathrm{mg} / \mathrm{L}$ prothioconazole. The isolate was considered sensitive to these fungicides. At $10 \mathrm{mg} / \mathrm{L}$, mycelial growth inhibition was $100 \%$ for prothioconazole. The strain was considered moderately sensitive to tebuconazole, showing $\mathrm{IC}_{50}$ of $1.41 \mathrm{mg} / \mathrm{L}$, and insensitive to cyproconazole, showing $\mathrm{IC}_{50}$ of $40 \mathrm{mg} / \mathrm{L}$ (Table 3).

For $05 / \mathrm{CD}$ strain, $\mathrm{IC}_{50}$ ranged from 0.17 to $34.08 \mathrm{mg} / \mathrm{L}$ for the five fungicides. The strain was classified as sensitive, showing values lower than $1 \mathrm{mg} / \mathrm{L}$ for epoxiconazole $(0.45 \mathrm{mg} / \mathrm{L})$ and prothioconazole $(0.17$ $\mathrm{mg} / \mathrm{L})$. Values greater than $1.0 \mathrm{mg} / \mathrm{L}$ were determined for propiconazole, tebuconazole and cyproconazole. The $\mathrm{IC}_{50}$ values were $1.17 \mathrm{mg} / \mathrm{L}$ (propiconazole) and $2.21 \mathrm{mg} / \mathrm{L}$ (tebuconazole), and the isolate was considered moderately sensitive to these active ingredients. Low sensitivity was detected for cyproconazole, $\mathrm{IC}_{50}$ of $34.08 \mathrm{mg} / \mathrm{L}$ (Table 3 ).

Interaction between isolates and fungicides was significant $(p$ $<0.05$ ) (Table 3 ). Among the five DMI fungicides tested in vitro, prothioconazole showed the lowest $\mathrm{IC}_{50}$ values for the five isolates; thus, it was the most efficient fungicide in inhibiting mycelium growth of $D t r$. The obtained values varied from 0.09 to $0.21 \mathrm{mg} / \mathrm{L}$ (Table 3). At $10 \mathrm{mg} / \mathrm{L}$, mycelial growth of the five isolates was completely inhibited.

The lowest IC $_{50}$ was observed for the strain 04/GUA to prothioconazole $(0.09 \mathrm{mg} / \mathrm{L})$. This fungicide was the most fungitoxic, presenting $\mathrm{IC}_{50}$ value of $0.09 \mathrm{mg} / \mathrm{L}$ (not statistically different from that of epoxiconazole and propiconazole). In the literature, no report on in vitro fungitoxicity and $\mathrm{IC}_{50}$ values was found for prothioconazole to $\mathrm{Dtr}$ isolated from wheat; however, this chemical can be highly promising in controlling the disease, according to our results (Table 3 ).

The highest $\mathrm{IC}_{50}$ values were determined for cyproconazole, between $28.11 \mathrm{mg} / \mathrm{L}$ and $>40.0$, indicating that, in vitro, the isolates were less sensitive to this fungicide. There was fungal mycelium growth, expressed as colony diameter, for all tested concentrations and for the five isolates (Table 3).

The active ingredient tebuconazole was classified as moderately fungitoxic to all tested isolates, statistically different from the other fungicides, except for 01/QTZ isolate to epoxiconazole (Table 3).

In the overall mean, prothioconazole was the most potent fungicide, followed by epoxiconazole, propiconazole and tebuconazole (Table $3)$.

Comparing the sensitivity of isolates, in the overall mean, to the five fungicides, 01/QTZ isolate from Ventania, PR, was the least sensitive but did not differ statistically from 03/HTZ from Julio de Castilhos, RS. 02/ONX from St. Augusto, RS, was the most sensitive isolate (Table 3).

SRF is a useful tool to quantify the shift in sensitivity of a fungus to a fungicide (11). Considering SRF, there was a reduction in sensitivity for the studied isolates. On average, among isolates, 01/QTZ from Ventania, PR, showed the highest SRF (2.24), and 04/GUA from Coxilha, RS, had the lowest SRF (1.20) (Table 4).

In the overall mean, SRF ranged from 1.36 to 2.23 , i.e., the isolates require a fungicide concentration from 1.36 to 2.23 times higher than that of the most sensitive isolate to obtain $50 \%$ reduction in the fungal mycelial growth (Table 3 ).

The development of fungal sensitivity shift to DMI is gradual and slow due to the polygenic or quantitative resistance type $(4,5,6,7$, 10 ). According to the same authors, fungal sensitivity reduction to DMI fungicides can be reversed to a condition of a higher fungal sensitivity when these fungicides are less extensively used and/or when alternative fungicides are used to control the disease.

\section{DISCUSSION}

Drechslera tritici-repentis sensitivity to triazoles. De Waard (7) stated that the evaluation of fungal resistance to DMI fungicides is difficult since the resistance level is frequently low and its development can only be detected when there is preliminary (baseline) data which can be used as reference $\mathrm{IC}_{50}$

Data reported by Stolte (22) for tebuconazole, $\mathrm{IC}_{50}<0.1$ for $0.32 \mathrm{mg} / \mathrm{L}$, and for cyproconazole, $\mathrm{IC}_{50}<0.1$ for $0.53 \mathrm{mg} / \mathrm{L}$, differed from our data, which included $\mathrm{IC}_{50}$ higher than those reported by that author, suggesting sensitive reduction of Dtr to DMI fungicides. That same author, conducting tests to monitor in vitro the mycelial sensitivity of Dtr isolates from wheat to fungicides in 2005, determined $\mathrm{IC}_{50}<1 \mathrm{mg} / \mathrm{L}$ for cyproconazole, epoxiconazole, propiconazole and tebuconazole. She considered the isolates were sensitive to these active ingredients. Beard et al. (3), in a sensitivity study conducted with $D t r$, reported $\mathrm{IC}_{50}$ of $0.19 \mathrm{mg} / \mathrm{L}$ for epoxiconazole, $0.39 \mathrm{mg} / \mathrm{L}$ for propiconazole, and $0.25 \mathrm{mg} / \mathrm{L}$ for tebuconazole. Hunger \& Brown (13), working with $\mathrm{Dtr}$, obtained $\mathrm{IC}_{50}$ of $0.04 \mathrm{mg} / \mathrm{L}$ for propiconazole and 0.19 $\mathrm{mg} / \mathrm{L}$ for tebuconazole. The $\mathrm{IC}_{50}$ for propiconazole found in our study ranged from 0.49 to $1.28 \mathrm{mg} / \mathrm{L}$, while for tebuconazole it varied from 
Table 4. Sensitivity reduction factor (SRF) of Drechslera tritici-repentis, isolated from wheat, to DMI fungicides

\begin{tabular}{lcccccc}
\hline \multirow{2}{*}{ Fungicide } & \multicolumn{3}{c}{ Isolates } & \multicolumn{2}{c}{ Mean } \\
\cline { 2 - 5 } & $\mathbf{0 1 / \text { QTZ }}$ & $\mathbf{0 2 / O N X}$ & $\mathbf{0 3 / H Z T}$ & $\mathbf{0 4 / G U A}$ & $\mathbf{0 5 / C D}$ \\
\hline Cyproconazole & $-*$ & - & - & - & - \\
Epoxiconazole & 3.91 & 1.00 & 3.17 & 1.80 & 1.28 \\
Propiconazole & 1.75 & 2.61 & 1.00 & 1.02 & 2.38 \\
Prothioconazole & 2.00 & 1.77 & 2.33 & 1.00 & 1.89 \\
Tebuconazole & 1.30 & 1.66 & 1.29 & 1.00 & 1.57 \\
\hline Mean & 2.24 & 1.61 & 1.95 & 1.20 & 1.80 & 1.66 \\
\hline
\end{tabular}

* Insensitive.

1.41 to $2.34 \mathrm{mg} / \mathrm{L}$. Comparing our values with those reported by Hunger \& Brown (13), $\mathrm{IC}_{50}$ has increased 12-32 times for propiconazole and 7-12 times for tebuconazole. The $\mathrm{IC}_{50}$ values determined in our study were superior to those found by other authors, indicating reduction in the sensitivity of Dtr to DMI.

Drechslera tritici-repentis sensitivity to strobilurins. QoI fungicides interfere with mitochondrial respiration by blocking electron transfer by the cytochrome bc1 complex, which interferes with ATP formation (Anesiadis). According to Anesiadis et al. (1), strobilurins act on the leaf surface, inhibiting the early stages of the infection process, such as spore germination, initial establishment and penetration of the pathogen.

Fungicides belonging to the same chemical group can show crossresistance. This means that a fungicide resistant to an isolate can also be resistant to another fungicide that has the same biochemical mode of action $(4,5,6,7,9)$. This fact was not proven in this study because there was differential interaction.

The sensitivity behavior among isolates to fungicides showed reduction/loss for QoI, evidencing that the selection pressure exerted by the continuous use of fungicides to control diseases in wheat crop may have led to a shift in sensitivity of the pathogen population to QoI fungicides. Rodrigues et al. (24) argued that, for strobilurins, there may be cross-resistance to azoxystrobin, pyraclostrobin and trifloxystrobin. Nevertheless, we do not have any explanation for the performance of pyraclostrobin, the most efficient fungicide for spore germination inhibition.

Dtr isolates showed less sensitivity $\left(\mathrm{IC}_{50}>40 \mathrm{mg} / \mathrm{L}\right)$ to azoxystrobin, kresoxim-methyl, trifloxystrobin and picoxystrobin in relation to spore germination. It is not known whether there was a shift because the baseline was not established when the individuals of the fungal population were still sensitive.

Even using only five isolates, we have shown differences in sensitivity among fungal strains and fungicide power. When a large number of fungicides and concentrations are used, the number of isolates has to be reduced. Thus, in the next step of this study, the number of isolates will be increased by using the collection of Dtr and D. siccans isolates (Tonin, Reis, Danelli) stored in the mycology collection of the Laboratory of Plant Pathology - Mycology, University of Passo Fundo, to track fungal sensitivity to only two fungicides, azoxystrobin and pyraclostrobin.

The use of fungicides must be managed according to anti-resistance strategies. These strategies are based on the principle that when there is fungicide application, a selection pressure is exerted on the pathogen population and can, in the long or short term, depending on the genetic mechanisms involved, result in the selection and predominance of the less sensitive individuals in the fungal population (11).

In the 2005/06 wheat growing season, after 20 years of DMI use, the first complaint of YLS control failure in Brazil was recorded (26).
According to our results, some Dtr isolates had a reduction in sensitivity to triazole fungicides but at different degrees. The fungicides tested in our study belong to the same family of triazoles and have the same mechanism of action, DMI (9). However, their potency differed among the representatives of the group. The fact of belonging to the same family did not assure that they had the same fungitoxicity.

The fungicide prothioconazole was most potent in inhibiting Dtr mycelial growth. Cyproconazole showed the highest $\mathrm{IC}_{50}$ values among the tested triazoles and was considered least fungitoxic.

Our results confirm the hypothesis that the failure to control YLS in wheat, observed in the last seasons, can be attributed to a reduction in the fungal sensitivity to the fungicides used to control the disease.

\section{REFERENCES}

1. Anesiadis, T; Karoaglanidis, G.S; Tzavella-Klonari, K. Protective, curative and eradicant activity of the strobilurin fungicide azoxystrobin against Cercospora beticola and Erysiphe betae. Journal of Phytopathology, Berlin, v. 151, p. 647-651, 2003.

2. Ardu im, F.S.; Reis, E.M.; Barcellos, A.L.; Turra, C. In vivo sensitivity reduction of Puccinia triticina races, causal agent of wheat leaf rust, to DMI and Q oI fungicides. Summa Phytopathologica, Botucatu, v. 38, n.4, p.306-311, 2012.

3. Beard, C.; Loughman, R.; Smith, A.; Speijers, J. Baseline sensitivity to three triazole fungicides in Pyrenophora tritici-repentis. Australasian Plant Pathology, p. 168-172, 2009.

4. Brent, K.J. Fungicide resistance in crop pathogens: how can it be managed? Brussels: FRAC Monograph 1. 1995.

5. Brent, K.J.; Hollomon, D.W. Fungicide resistance: The assessment of risk FRAC Monograph No 2, Global Crop Protection Federation, Brussels, 48p, 1998.

6. Dekker, H. Development of resistance to modern fungicides and strategies for its avoidance. In: LYR, H. (Ed.). Modern selective fungicides: properties, applications, mechanisms of action. 2. ed. New York: Gustav Fisher, p.23-38, 1995.

7. De Waard, M.A. Resistance to Fungicides Which Inhibit Sterol $14 \alpha$ - Demethylation, an Historical Perspective. In: Heaney S, Slawson D, Hollomon DW, Smith M, Russell PE, Parry DW Fungicide Resistance. Farnham: The British Crop Protection Council, p.3-10, 1994.

8. Edgington, L.V.; Khew, K.L.; Barrow, G.L. Fungitoxic spectrum of benzimidazole compounds. Phytopathology, St. Paul, v. 61, p. 42- 44, 1971.

9. FRAC. Fungicides sorted by mode of action (including FRAC Code numbering). http://www.frac.info/frac/publication/anhang/FRAC Code List 2011.pdf. 2011.

10. Georgopoulos, S.G. Genetical and biochemical bachground of fungicide resistance. In: Dekker J, Georgopoulos SG Fungicide Resistance in Crop Protection. Wageningen: Centre for Agricultural Publishing and Documentation, p. 46-52,1982.

11. Ghini, R.; Kimati, H. Resistência de fungos a fungicidas. Jaguariúna: Embrapa Meio Ambiente, p. 78, 2000.

12. Hosford, R.M. Jr. A form of Pyrenophora trichostoma pathogenic to wheat and other grasses. Phytopathology, St. Paul, v. 61, p. 28-32, 1971.

13. Hunger, R.M.; Brown, D.A. Colony color, growth, sporulation, fungicide 
sensitivity, and pathogenicity of Pyrenophora tritici-repentis. Plant Disease, St. Paul, v.71, p. 907-910. doi: 10.1094/PD-71-0907, 1987.

14. Krupinsky JM (1992) Grass hosts of Pyrenophora tritici-repentis. Plant Disease, St. Paul, v.76, n.1, p.92-95.

15. Rees, R.G.; Platz, G.J. Effects of Yellow Spot on Wheat: Comparision of Epidemics at Different Stages of Crop Development. Australian Journal of Agricultural Research 34, p. 39-46, 1983.

16. Reis EM, Casa RT (2007) Doenças dos cereais de inverno: diagnose, epidemiologia e controle. 2.ed. Lages: Graphel, 176 p.

17. Reis, E.M.; Basso, D.F.; Zanatta, M. Loss of sensitivity of Blumeria graminis f. sp. tritici to triadimenol applied as seed treatment.Tropical Plant Pathology, Brasília, v. 38, n. 1, p. 055-057, 20132013.

18. REUNIÃO DA COMISSÃO SUL BRASILEIRA DE PESQUISA DE TRIGO, 17., 1985, Cruz Alta. Recomendações da Comissão Sul-Brasileira de Pesquisa do Trigo para a cultura do trigo em 1985. Cruz Alta: Fecotrigo-CEP, 1985. $55 \mathrm{p}$.

19. REUNIÃO DA COMISSÃO SUL BRASILEIRA DE PESQUISA DE TRIGO, 22., 1990, Porto Alegre. Recomendações da Comissão Sul Brasileira de Pesquisa de Trigo - 1990. Cruz Alta: FUNDACEP FECOTRIGO, 1990. $60 \mathrm{p}$.

20. REUNIÃO DA COMISSÃO SUL BRASILEIRA DE PESQUISA DE TRIGO, 24.,1992, Cruz Alta. Recomendações da Comissão Sul Brasileira de Pesquisa de Trigo-1992. Cruz Alta: FUNDACEP-FECOTRIGO, 1992. $47 \mathrm{p}$.

21. REUNIÃO DA COMISSÃO SUL-BRASILEIRA DE PESQUISA DE TRIGO, 31., 1999, Passo Fundo. Recomendações da Comissão Sul
-Brasileira de Pesquisa de Trigo - 1999. Passo Fundo: Embrapa Trigo, 1999. $86 \mathrm{p}$.

22. REUNIÃO DA COMISSÃO BRASILEIRA DE PESQUISA DE TRIGO E TRITICALE, 5., 2011, Dourados. Informações técnicas para trigo e triticale - safra 2012. Dourados: Embrapa Agropecuária Oeste, 2011. 204 p. (Embrapa Agropecuária Oeste. Sistema de produção, 9).

23. REUNIÃO DA COMISSÃO BRASILEIRA DE PESQUISA DE TRIGO E TRITICALE (8. : $2014:$ Canela, RS). Informações técnicas para trigo e triticale - safra 2015 / VIII Reunião da Comissão Brasileira de Pesquisa de Trigo e Triticale; Gilberto Rocca da Cunha e Eduardo Caierão, editores técnicos. - Brasília, DF : Embrapa, 2014.

24. RODRIGUES, M.B.C.; ANDREOTE, F.D.; SPÓSITO, M.B.; AGUILLARVILDOSO, C.I.; ARAÚJO, W.L.; PIZZIRANIKLEINER, A.A. Resistência a benzimidazóis por Guignardia citricarpa. Pesquisa Agropecuária Brasileira, Brasília, v.42, n.3, p.323-327, 2007.

25. Russell, P. E. 2004. Sensitivity baselines in fungicide resistanc and manag gement. FRAC Monograph No. 3, 2004. Brussels. http://www.frac.info/ publication/anhang/monograph3.pdf.

26. Stolte, R.E. Sensibilidade de Bipolaris sorokiniana e de Drechslera tritici-repentis a fungicidas in vitro. Dissertação (Mestrado em Agronomia) - Universidade de Passo Fundo/UPF. Passo Fundo/RS. 103 p, 2006.

27. Tonin, R.F.B.; Reis, E.M.; Danelli, A.L.D. Etiologia e quantificação dos agentes causais de manchas foliares na cultura do trigo nas safras 2008 a 2011. Summa Phytopathologica, Botucatu, v.39, n.2, p.102-109, 2013.

28. Zadoks JC, Schein R (1979) Epidemiology and Plant Disease Management. New York: Oxford University Press, 427 p. 